\title{
MAX WEBER \\ (1864-1920)
}

\author{
HIDAS ZOLTÁN
}

Szociológus, társadalomfilozófus, Émile Durkheim mellett a szociológia egyik „alapító atyja”. A jogi végzettségü Weber alig harminc évesen a közgazdaságtan professzora lett, és rövid ideig gazdaságtörténeti és -elméleti tárgyú előadásokat tartott a Freiburgi és a Heidelbergi Egyetemen. Súlyos idegösszeomlását követően, amely hosszú időre munka- és időlegesen beszédképtelenné is tette, kényszerűen kivált az akadémiai életből, és élete utolsó évét leszámítva, amikor a Müncheni Egyetemen újból tanítani kezdett, magántudósként dolgozott. A heidelbergi otthonában szerveződő vasárnapi beszélgetéseken a kor számos jelentős értelmiségije megfordult (Georg Simmel, Bloch, Jaspers, Friedrich Gundolf, Lukács György). A politika iránt - részben családi hagyományok alapján is - szenvedélyes érdeklödést tanúsított, de tartományi képviselőválasztásokon elszenvedett kudarca miatt végleg a tudomány felé fordult. Politikailag nemzeti és liberális elveket vallott; részt vett a weimari alkotmány kidolgozásában (1918). Spanyolnáthában hunyt el, hatalmas életművének egyes darabjait halála előtt rendezte kötetbe.

A humántudományok terén máig jelentősek Weber korai, ismeretelméletileg kidolgozott módszertani írásai (Gesammelte Aufsätze zur Wissenschaftslehre, 1922, „Összegyüjtött tudománytani tanulmányok”), amelyekben - a betegségből lábadozva, részben öntisztázó szándékkal - a természettudományokkal szembeállított kultúratudományok elvi megalapozására törekedett. Ezek megismerési érdeke az általános helyett az egyedire irányul, mindenekelőtt a minket körülvevő valóságnak és kialakulásának a tapasztalati megismerése érdekében. A megismerés eszközei az ideáltípusok, amelyek a jelenségek és folyamatok rekonstruálására törekvő zárt, „utópikus” gondolati alakzatok: a valóság kimeríthetetlen végtelenségéből, amelyet a fogalmak sohasem képesek lefedni, sajátos szempontok szerint a mi számunkra jelentőset választjuk ki, és következetesen egységesítjük. A kultúratudományok elöfeltétele, hogy a kultúra embere a világ önmagában értelemmentes részeihez értelmet kapcsol és velük kapcsolatban állást foglal.

A módszertani szempontból szándékosan egyoldalú Die protestantische Ethik und der Geist des Kapitalismus (1904/1905, átdolgozva 1920, magyarul: A protestáns etika és a kapitalizmus szelleme, 2020) a materiális meghatározottságokat figyel- 
men kívül hagyva a puritán protestáns éthosz - nem szándékolt - hatását vizsgálja a kapitalista mentalitás kialakulására, vagyis nem a kapitalizmus egészének (pl. a formájának) a megszületése foglalkoztatja, és nem tárgyal más szellemi hatóerőket sem. A mű elméleti-módszertani szempontból a történelmi materializmus pozitív kritikája. Az eredeti újdonság a gazdasági racionalitás vallási hajtóerejének - azóta is rendszeresen vitatott - kimutatása: a predesztinációtan és hozzá kapcsolódva a beigazolódásgondolat felmérhetetlen hatása. Egy elvi igényü megfogalmazás szerint az emberek cselekvését nem eszmék, hanem anyagi és eszmei (pl. megváltásra törekvés) érdekek uralják, de „az »eszmék« által teremtett »világképek« váltó gyanánt igen sokszor meghatározták, hogy milyen pályákra terelte a cselekvést az érdekek dinamikája” („Bevezetés” a Világvallások gazdasági etikája című gyüjteményhez, Wirtschaftsethik der Weltreligionen, 3 kötet, magyarul válogatás, 2007, 65). A munkájához az újkori ember hivatásként viszonyul, amely a protestáns számára még az üdvösség beigazolásának eszköze volt, mi viszont már „acélkemény burokként" (A protestáns etika, 186) örököljük a kapitalizmus rendjét. Az egységes életvitel eredetileg próféták által hirdetett követelménye itt vált nemcsak a vallási „virtuózok”, hanem a tömegek számára is érvényes elvárássá: a világalakítás elve a kolostorokból kilépve világon-belüli aszkézisként, azaz Isten dicsőségére végzett világi munkaként terjedt el.

A művek horizontja fokozatosan világtörténelmivé tágul, összehasonlító szellemben megnyílva a távol-keleti kultúrák (Kína, India) és a saját múlt (az ókori zsidóság) felé. Időközben minden írás egyre következetesebben a modern nyugati világ sajátos racionalitása köré szerveződik, Weber müve pedig a racionalizmus sokféleségének „szociológiájává és tipológiájává” bővül („Zwischenbetrachtung”, 1920, magyarul „Közbevetett megfontolások”, in Világvallások, 205). A racionalizmus történeti fogalom, mivel a világ sokféle szféráját és többféle szempont szerint lehet racionalizálni. A kultúrák eltérő irányokba szervezték meg, azaz racionalizálták a világhoz való viszonyulást, a világ eredendő irracionalitásának tapasztalataiból kiindulva. Bár a kultúrvallások legtöbbje egyformán a világgal való elvi feszültségre épül, a megváltásvallások világelutasítása körében - a személytelen isteni világrend és a személyes túlvilági cselekvő Isten képzetével is összhangban a világból való menekülés (buddhizmus) és a tevékeny világuralás (puritanizmus) lehetőségei bontakoztak ki következetes módon. Utóbbi a reformáció terjedése nyomán vált hatásossá az újkori nyugati világban, amely a világ varázstalanodásában (Entzauberung) a legtovább jutott (vö. A protestáns etika, 81). Bár legszükebb értelme szerint e metafora az üdvösségszerzés mágikus-kényszerítő eszközeinek), legvégül az egyházi és szentségi közvetítésnek a kiiktatását jelenti, Weber ezt később egy több évezredes folyamatba illesztette bele, amely a bibliai próféták egyedül Jahvéhoz hüséges következetességével vette kezdetét, és az újkori tudományosság empirizmusában végződött (lásd még „Közbevetett megfontolások”, 
230). A világ immanens oksági mechanizmussá racionalizálódott és intellektualizálódott, amelyhez a kalkuláló uralhatóság hitével viszonyulunk, így a vallás minden világi szemponthoz képest az irracionalitásba szorult. Ennek egyik vetülete a vallásosság belülre települése és az egyén rendkívüli elmagányosodása, ami már csak a túlvilági kötelékek elszakadásával fokozódhatott még tovább. A modernség leírásának egyik meghatározó fogalmaként honosodott meg a „varázstalanodás” Weber által vázolt jelensége, bár a fogalmat sokszor a szekularizációra redukálják vagy a racionalizációval azonosítják.

A tapasztalati alapú társadalomtudományok feltárják az életszférák egymáshoz való viszonyának alakulásait és elvi összefüggéseit. A Wirtschaft und Gesellschaft (1921, magyarul Gazdaság és társadalom, $1987 \mathrm{skk}$.) címen megjelent hatalmas torzó, amely a vallásszociológiai tanulmányokkal párhuzamosan készült, a gazdaság, az uralom, a jog és a vallás rendjeit általánosító igénnyel rendszerezi, hogy a kultúrák konkrét elemzéséhez is megfelelő fogalmakat kínáljon. Weber mindaddig nem tekintette magát szociológusnak, amíg ki nem dolgozta saját, megértő szociológiáját, amelyben a megértés a cselekvések szubjektív értelmének, tágabb értelmi összefüggéseinek megértésére vonatkozik, mivel az emberi világban a szándékok mint okok bevonásával lehetséges oksági magyarázat. A szociológia középpontjában a cselekvő individuum áll, akinek megismerő tevékenységét is a megismerendőkben való érintettsége vezérli. A társadalmi kapcsolatok, a tágabb „rendek” (amilyen pl. a nemzet), továbbá az intézményesült szervezetek hordozói is mindig egyének, akik egymással harcban és szolidáris kapcsolatban lehetnek. A puszta érdekegyezésből csak közös cselekvésvezérlő elvek teremtenek tartós rendet, amelynek megléte a hozzá való igazodás esélyét jelenti. Az esszencialista implikációk miatt Weber soha nem használja a társadalom fogalmát.

Weber egész gondolkodásán végigvonul az értékeléstől való tudományos tartózkodás parancsa: empirikus tényállításokból értékítéletek levezethetetlenek, a világnézetek nem a halmozódó tapasztalati tudás eredményei. Wissenschaft als Beruf (1919, „A tudomány mint hivatás” in Tanulmányok, 1998) címü híres beszédének kordiagnózisa szerint mára a világ egymást metsző szférái ugyanazt a világot rendezik egyre következetesebben más és más végső szempontok köré. A gazdaság, a politika és a tudomány személytelenül racionális „kozmoszai” a vallások számára ma már végérvényesen megközelíthetetlenek: princípiumaikban különböznek egymástól. A különböző életszférák között ma mindinkább $\rightarrow$ értékek kiengesztelhetetlen harca folyik, és még az egyes szférákon belül is döntésekre van szükség a végső elvi lehetőségek között. Az etika mellett más értékek is - mindenekelött az üdvösség, az igazság, a szép, a hatalom - érvényt követelnek az ember életében, és még az igazságosság mércéje sem véglegesíthető az etikán belül. Ezt nevezi Weber a jelenkor „politeizmusának” (Tanulmányok, 148). A személyes választás elkerülhetetlensége, a következetesség parancsa és az ellentmondások elvi- 
selése egy egzisztenciális felfogás gondolati alakzatai, bár Weber szemléletét szokás nihilistának vagy decizionistának minősíteni. A személyiség konstans egységét az teremti meg, hogy végső döntések láncolatban saját ügyének szenteli magát, amelyet egy „prófétátlan és istenidegen” korban végül is a „saját kebeléből” kell merítenie, így döntése hitbeli aktus. Politik als Beruf (1919, „A politika mint hivatás”, in Tanulmányok, 1998) című beszédében Weber különbséget tesz az „érzületetika” és a „felelősségetika” között. Utóbbi az érzületen túlmenően tettei belátható következményeiért is vállalja a felelősséget. Az uralom típusainak elmélete a politikai berendezkedések hagyományos kategorizálásától eltérően az uralom elfogadottságának alapjára kérdez (karizmatikus, bürokratikus, tradicionális legitimitás). Hatalomelvű politikafelfogása és az erőszakra épülő államfogalma jelentős hatással volt a politikai gondolkodására, pl. Carl Schmittre; de politikusok, pl. Helmut Schmidt (1918-2015) számára is mértékadó volt a reálpolitika weberi programja.

Maga Weber elutasította, hogy tapasztalati szaktudományként kidolgozott szociológiájának közvetlen filozófiai igényei lennének, de a tudományos racionalitást a jelenkori öneszmélés nélkülözhetetlen összetevőjének tartotta. Gondolkodásának filozófiai hatásai közül Jaspers egész gondolkodása emelkedik ki, aki Webert a jelenkori filozófia személyes megtestesülésének tekintette. Művének szellemi fesztávja minden holisztikus igény nélkül is filozófiai jelleget mutat, az újkori világhelyzetről alkotott elgondolásai és egyes fogalmai pedig (mint a protestáns etika tézise, a varázstalanodás) minden vitatottságuk ellenére is megújuló elgondolkodásra késztetnek.

\section{TOVÁBBI IRODALOM}

Henrich, Dieter: Die Einheit der Wissenschaftslehre Max Webers (1952).

Hidas Zoltán: A varázstalanság metafizikája (2021).

Jaspers, Karl: Max Weber. Gesammelte Schriften (1988).

Löwith, Karl: Karl Marx und Max Weber (1932). 